\title{
(1) cossiber \\ Congenital adrenal hyperplasia with salt-wasting crisis and arrhythmia: a case study
}

\author{
Johnny Figueroa Canlas, Caroline Ponmani
}

Department of Paediatrics, Barking Havering and Redbridge University Hospitals NHS Trust, Romford, UK

\section{Correspondence to} Dr Johnny Figueroa Canlas, jfcanlas@yahoo.co.uk

Accepted 1 January 2019

\section{Check for updates}

(C) BMJ Publishing Group Limited 2019. Re-use permitted under CC BY-NC. No commercial re-use. See rights and permissions. Published by BMJ.

To cite: Canlas JF, Ponmani C. BMJ Case Rep 2019;12:e227565. doi:10.1136/bcr-2018227565

\section{SUMMARY}

We report a case of a 10-day-old male infant who presented to the emergency department with severe electrolyte imbalance and life-threatening arrhythmia. The parents reported a 3-day history of poor feeding and lethargy. On examination, he was bradycardic (heart rate of 65 beats $/ \mathrm{min}$ ) with signs of dehydration. His ECG showed broad complex bradycardia. Blood gas showed metabolic acidosis with hyponatraemia and hyperkalaemia. A probable diagnosis of congenital adrenal hyperplasia (CAH) with salt-wasting crisis was made and treatment was commenced. He was given saline bolus, nebulised salbutamol, calcium gluconate and hydrocortisone. Following the above interventions, his heart rate rose to 150 beats/min with a regular sinus rhythm within a period of $40 \mathrm{~min}$. The diagnosis of $\mathrm{CAH}$ secondary to 21-hydroxylase deficiency with mutation in CYP21A2 was confirmed by genetic studies. He was discharged home with hydrocortisone, fludrocortisone and sodium chloride.

\section{BACKGROUND}

We present this case with a view to focus on this medical emergency and to keep congenital adrenal hyperplasia $(\mathrm{CAH})$ as a differential in any neonate who presents with arrhythmias or unresponsive shock so that paediatricians could manage this problem in a timely manner. It is also important to consider this disorder in all cases of otherwise unexplained electrolyte and metabolic abnormalities during the first few weeks of life.

\section{CASE PRESENTATION}

A 10-day-old male infant presented to the emergency department with a 3-day history of poor feeding and lethargy. No fever or irritability was noted. He was born at 40 weeks' gestation by emergency caesarean section with no complications. $\mathrm{He}$ had an Apgar scores of 7,9 and 9 at $1 \mathrm{~min}, 5 \mathrm{~min}$ and $10 \mathrm{~min}$, respectively. His birth weight was $2.80 \mathrm{~kg}$ (2nd-9th centile); length $49.0 \mathrm{~cm}$ (25th centile) and head circumference $36.0 \mathrm{~cm}$ (9th-25th centile).

His antenatal scans were normal; maternal serology protective and he had no risk factors for sepsis. He was the first child of consanguineous parents (first cousins) of Bangladeshi descent. He had an older brother who was apparently healthy. There were no chronic diseases that run in the family.

On initial examination, he was crying, alert, but bradycardic (heart rate of 65 beats/min), with sunken eyes, normal oral mucosa and a slightly depressed anterior fontanelle. His respiratory rate was 50 breaths/ min and was saturating at 99\% in air. His preductal oxygen saturation was $98 \%$ in air and postductal oxygen saturation was $97 \%$ in air. His chest was clear and he had a 2/6 systolic murmur best heard in the pulmonary area. Examinations of the respiratory system and abdomen were within normal limits.

His ECG showed broad complex bradycardia. His blood pressure was recorded as 92/56 $\mathrm{mm} \mathrm{Hg}$ (above 50th centile). His initial blood gas showed the following: $\mathrm{pH} 7.30$ (7.35$7.45), \quad \mathrm{HCO}_{3} \quad 16.1 \mathrm{mmol} / \mathrm{L} \quad(22-28 \mathrm{mmol} / \mathrm{L})$, $\mathrm{BE} \quad-9.0 \mathrm{mmol} / \mathrm{L} \quad(-4.0$ to $+4.0 \mathrm{mmol} / \mathrm{L}), \quad \mathrm{Na}$ $112 \mathrm{mmol} / \mathrm{L} \quad(135-145 \mathrm{mmol} / \mathrm{L}), \quad \mathrm{K} \quad 9.7 \mathrm{mmol} / \mathrm{L}$ $(3.5-5.0 \mathrm{mmol} / \mathrm{L})$, ionised $\mathrm{Ca} 1.16 \mathrm{mmol} / \mathrm{L}(1.0$ $1.3 \mathrm{mmol} / \mathrm{L})$, glucose $3.9 \mathrm{mmol} / \mathrm{L}(3.0-6.5 \mathrm{mmol} / \mathrm{L})$ and lactate of $3.3 \mathrm{mmol} / \mathrm{L}(<2 \mathrm{mmol} / \mathrm{L})$.

Treatment with intravenous cefotaxime $(25 \mathrm{mg} /$ $\mathrm{kg}$ ) and intravenous amoxicillin $(30 \mathrm{mg} / \mathrm{kg})$ was commenced for suspected sepsis. However, the hyponatraemia and hyperkalaemia were out of proportion to his clinical condition. Following the results of the blood gas, his genitalia was examined and was noted to have normal male genitalia. The pigmentation of the genitalia was noted to be darker than the infant's skin tone. A probable diagnosis of CAH with salt-wasting crisis with arrhythmia was made and treatment was commenced.

$\mathrm{He}$ was given high flow oxygen via non-rebreathing mask; $20 \mathrm{~mL} / \mathrm{kg}$ of $0.9 \%$ saline bolus; continuous nebulised salbutamol $(2.5 \mathrm{mg})$; stat dose of calcium gluconate intravenously $(0.11 \mathrm{mmol} /$ $\mathrm{kg}$ ); hydrocortisone intravenously $(4 \mathrm{mg} / \mathrm{kg})$ and fludrocortisone acetate $(50 \mathrm{mcg})$. Sodium bicarbonate infusion $(1 \mathrm{mmol} / \mathrm{kg})$ was also commenced. Following the administration of the above interventions, his heart rate rose to 150 beats $/ \mathrm{min}$. His repeat ECG showed regular sinus rhythm within a period of $40 \mathrm{~min}$ of arrival to the emergency department. An echocardiogram was done, and it was normal.

A diagnosis of CAH secondary to 21-hydroxylase deficiency with mutation in CYP21A2 was confirmed by genetic studies. His glucose and electrolytes have been monitored daily while in the hospital, and they gradually improved to satisfactory levels.

$\mathrm{He}$ was discharged home with oral hydrocortisone ( $2 \mathrm{mg} / \mathrm{kg} 6$ hourly), fludrocortisone acetate (50 mcg once daily) and $0.9 \%$ sodium chloride $(1 \mathrm{mmol} /$ $\mathrm{kg}$ twice daily). An instruction to his parents was given to double the dose of his oral hydrocortisone if the baby has intercurrent illness (eg, fever, cough, 
vomiting and diarrhoea). They were also given an emergency card/passport so that he can be assessed and managed immediately by the paediatric team whenever he presents to the hospital.

\section{INVESTIGATIONS}

1. 17-hydroxyprogesterone: $280 \mathrm{nmol} / \mathrm{L}(<20 \mathrm{nmol} / \mathrm{L})$.

2. Genetic test: CAH secondary to 21-hydroxylase deficiency with mutation in CYP21A2.

\section{DIFFERENTIAL DIAGNOSIS}

In a small baby who presents with lethargy, electrolyte imbalance and arrhythmia, the following are some of the differential diagnoses that need to be addressed: (1) neonatal sepsis can present with subtle changes in baby's behaviour and vital signs. The three most common organisms that can cause neonatal sepsis are Group B Streptococcus, Escherichia coli and Listeria monocytogenes. Our patient received intravenous cefotaxime and intravenous amoxicillin to cover for these micro-organisms. (2) An infant with congenital heart disease can present with lethargy, poor feeding, respiratory distress and arrhythmia. Chest X-ray, ECG and echocardiogram should be done to rule out this condition. (3) Other metabolic disorders such as fatty oxidation and urea cycle defects can present with lethargy, poor feeding, electrolyte imbalance and a life-threatening arrhythmia. The presence of urinary ketone can rule out fatty acid oxidation defect and a very high ammonia level supports the diagnosis of urea cycle defect.

\section{TREATMENT}

1. Resuscitation management

a. High flow oxygen via non-rebreathing mask.

b. Intravenous antibiotics (cefotaxime $25 \mathrm{mg} / \mathrm{kg}$ and amoxicillin $30 \mathrm{mg} / \mathrm{kg}$ ) to cover for suspected sepsis.

c. $0.9 \%$ sodium chloride bolus $(20 \mathrm{~mL} / \mathrm{kg})$ to treat shock.

d. Continuous nebulised $(2.5 \mathrm{mg})$ salbutamol for hyperkalaemia.

e. Calcium gluconate IV $(0.11 \mathrm{mmol} / \mathrm{kg})$ for cardioprotection.

f. Oral Calcium resonium $(0.3 \mathrm{~g} / \mathrm{kg})$ for hyperkalaemia.

2. Endocrine management

a. Intravenous hydrocortisone while in the hospital $(4 \mathrm{mg} /$ kg six hourly).

b. Oral hydrocortisone on discharge $(2 \mathrm{mg} / \mathrm{kg}$ six hourly).

c. Oral fludrocortisone acetate $(50 \mathrm{mcg}$ once daily).

d. Oral $0.9 \%$ Sodium Chloride $(1 \mathrm{mmol} / \mathrm{kg}$ twice daily).

e. Double the dose of oral hydrocortisone if child has intercurrent illness and attend emergency department.

\section{OUTCOME AND FOLLOW-UP}

The patient was managed for 2 weeks in the local hospital and made good progress. He was discharged home with oral hydrocortisone $(2 \mathrm{mg} / \mathrm{kg}$ six hourly), fludrocortisone acetate $(50 \mathrm{mcg}$ once daily) and $0.9 \%$ sodium chloride $(2 \mathrm{mg} / \mathrm{kg}$ twice daily). He was followed-up both at the local and tertiary hospital and he has been growing and thriving well. His weight falls along the 25th-50th centile and his height along the 9th-25th centile. His electrolytes have been checked every 4 weeks and his medications have been adjusted accordingly based on his current weight.

\section{DISCUSSION}

$\mathrm{CAH}$ is a group of inherited disorders that are present at birth where the adrenal glands are hyperplastic. ${ }^{1}$ In $\mathrm{CAH}$, the body is missing an enzyme that stimulates the adrenal gland to release cortisol. More than $90 \%$ of cases of CAH are caused by 21-hydroxylase deficiency due to mutations in CYP21A2 gene. ${ }^{2}$

The most important variant is the salt-losing crisis presenting as a medical emergency. These patients cannot synthesise sufficient aldosterone to maintain sodium balance and may develop potentially fatal 'salt-wasting' crisis if not treated. Females with classic 21-hydroxylase deficiency are exposed to excess androgens prenatally and are born with virilised external genitalia. ${ }^{3}$ Males have no genital ambiguity to alert physicians before the onset of dehydration and shock, hence the diagnosis is particularly critical in them. ${ }^{4}$ If $\mathrm{CAH}$ is not diagnosed and treated early, neonates are susceptible to sudden death in the first few weeks of life. ${ }^{5-8}$

Mass screening for 21-hydroxylase deficiency started in Japan in January 1989, and one per 18000-19000 infants are found to have 21-hydroxylase deficiency (OHD). Many patients with 21-OHD have skin pigmentation, virilisation of the external genitalia (females), poor suckling and poor weight gain, but others have $21-\mathrm{OHD}$ with only very mild clinical symptom. ${ }^{8}$

There have been some reports of $\mathrm{CAH}$ in neonates with saltlosing crisis but without arrhythmia. ${ }^{5}$ Our patient presented with hyponatraemia, hyperkalaemia and a life-threatening arrhythmia. The recognition and appropriate medical management in the emergency unit has prevented fatality. Finally, a combination of hyperkalaemia and hyponatraemia with metabolic acidosis is suggestive of adrenal insufficiency and treatment with hydrocortisone gives excellent response. ${ }^{8}$

\section{Learning points}

A combination of hyperkalaemia and hyponatraemia with metabolic acidosis is suggestive of adrenal insufficiency and treatment with hydrocortisone gives excellent response. An urgent and appropriate management of salt-wasting crisis is very important to prevent fatality. Always consider congenital adrenal hyperplasia (CAH) as a differential diagnosis in any neonate who presents with arrhythmia or unresponsive shock.

- Neonatal screening for 21-hydroxylase deficiency identifies both male and female affected infants, prevents incorrect sex assignment and decreases mortality and morbidity. It is a very sensitive test to detect almost all infants with classical CAH and also some infants with non-classical CAH.

- Currently, neonatal screening for 21-hydroxylase deficiency is not routinely done in the UK. Our index patient has presented with a life-threatening condition due to undiagnosed CAH secondary to 21-hydroxylase deficiency. We recommend that screening for 21-hydroxylase deficiency should be included in the neonatal screening programme in the UK and other parts of the world in the near future.

Contributors JFC has written up the first draft of manuscript and did literature search. CP has written up the final manuscript and did literature search.

Funding The authors have not declared a specific grant for this research from any funding agency in the public, commercial or not-for-profit sectors.

Competing interests None declared.

Patient consent for publication Obtained.

Provenance and peer review Not commissioned; externally peer reviewed.

Open access This is an open access article distributed in accordance with the Creative Commons Attribution Non Commercial (CC BY-NC 4.0) license, which permits others to distribute, remix, adapt, build upon this work non-commercially, and license their derivative works on different terms, provided the original work 
is properly cited and the use is non-commercial. See: http://creativecommons.org/ licenses/by-nc/4.0/

\section{REFERENCES}

1 Gialluisi A, Menabò S, Baldazzi L, et al. A genetic epidemiology study of congenital adrenal hyperplasia in Italy. Clin Genet 2018;93:223-7.

2 White PC, Speiser PW. Congenital adrenal hyperplasia due to 21-hydroxylase deficiency. Endocr Rev 2000;21:245-91.

3 Fleming L, Knafl K, Van Riper M. How the child's gender matters for families having a child with congenital adrenal hyperplasia. J Fam Nurs 2017;23:516-33.
4 Kovács J, Votava F, Heinze G, et al. Lessons from 30 years of clinical diagnosis and treatment of congenital adrenal hyperplasia in five middle European countries. J Clin Endocrinol Metab 2001;86:2958-64.

5 Rossignol P, Legrand M, Kosiborod M, et al. Emergency management of severe hyperkalemia: Guideline for best practice and opportunities for the future. Pharmacol Res 2016;113:585-91.

6 Weisberg LS. Management of severe hyperkalemia. Crit Care Med 2008;36:3246-51.

7 Masilamani K, van der Voort J. The management of acute hyperkalaemia in neonates and children. Arch Dis Child 2012;97:376-80.

8 Ishii T, Anzo M, Adachi M, et al. Guidelines for diagnosis and treatment of 21-hydroxylase deficiency (2014 revision). Clin Pediatr Endocrinol 2015;24:77-105.

Copyright 2019 BMJ Publishing Group. All rights reserved. For permission to reuse any of this content visit

https://www.bmj.com/company/products-services/rights-and-licensing/permissions/

BMJ Case Report Fellows may re-use this article for personal use and teaching without any further permission.

Become a Fellow of BMJ Case Reports today and you can:

- Submit as many cases as you like

- Enjoy fast sympathetic peer review and rapid publication of accepted articles

- Access all the published articles

- Re-use any of the published material for personal use and teaching without further permission

For information on Institutional Fellowships contact consortiasales@bmjgroup.com

Visit casereports.bmj.com for more articles like this and to become a Fellow 